\begin{tabular}{|cc}
\hline KEB UNMUL. & K I N E R J A 15 (1), 2018 29-37 \\
http://journal.feb.unmul.ac.id/index.php/KINERJA
\end{tabular}

\title{
Pengaruh perencanaan karir, pelatihan dan pengembangan karir terhadap kinerja karyawan
}

\author{
Rajib Mulyadi ${ }^{1}$, Tetra Hidayati ${ }^{2}$, Siti Maria ${ }^{3}$ \\ Fakultas Ekonomi dan Bisnis Universitas Mulawarman, Samarinda. \\ ${ }^{1}$ Email: eajibmulyadi62@gmail.com \\ ${ }^{2}$ Email: tetra.hidayati@feb.unmul.ac.id \\ ${ }^{3}$ Email: siti.maria@feb.unmul.ac.id
}

\begin{abstract}
Abstrak
Perencanaan Karir, Pelatihan dan Pengembangan Karir merupakan salah satu dari berbagai faktor yang mempengaruhi Kinerja Karyawan. Penelitian ini bertujuan untuk menguji dan menganalisis Perencanaan Karir, Pelatihan dan Pengembangan Karir PT. Bank Negara Indonesia (Persero) Tbk Samarinda. Penelitian ini dilakukan menggunakan regresi linier berganda dengan sebutan SPSS versi 16 dalam menganalisis data. Hasil Pengujian hipotesis menunjukan bahwa Perencanaan Karir, Pelatihan dan Pengembangan Karir memiliki pengaruh positif signifikan terhadap Kinerja Karyawan PT. Bank Negara Indonesia (Persero) Tbk Samarinda.
\end{abstract}

Kata Kunci: perencanaan karir; pelatihan; pengembangan karir; kinerja karyawan

\section{The influence of career planning, training and career development on employee performance}

\begin{abstract}
Career Planning, Training and Career Development is one of several factors that affect to the Performance of employee. This research aims to examine and analyze Career Planning, Training and Career Development to the Employee Performance of PT. Bank Negara Indonesia (Persero) Tbk of Samarinda. This research conducted using multiple linear regression called SPSS version 16 in analyzing the data. Hypothesis testing result show that Career Planning, Training and Career Development has a positive and significant impact on the Employee Performance of PT. Bank Negara Indonesia (Persero) Tbk of Samarinda.
\end{abstract}

Keywords: career planning; training; career development; employee performance 


\section{PENDAHULUAN}

Kinerja merupakan istilah yang tenar di dalam manajemen, yang mana istilah kinerja diartikan sebagai istilah hasil kerja, prestasi kerja dan performance. Salah satu hal yang dapat dijadikan parameter tentang kualitas sumber daya manusia adalah tingkat kinerja yang ada pada sumber daya manusia tersebut. Dessler (2009) mengemukakan pentingnya penilaian kinerja berarti mengevaluasi kinerja karyawan saat ini dan/atau dimasa lalu relatif terhadap standar prestasinya dan manajemen kinerja sebagai proses mengkonsulidasikan penetapan tujuan, penilaian dan pengembangan kinerja kedalam satu sistem tunggal bersama, yang bertujuan memastikan kinerja karyawan mendukung strategis perusahaan. Oleh karna itu organisasi harus mampu menjaga dan meningkatkan kinerja serta memaksimalkan potensi dari sumber daya manusia tersebut.

Masalah akan kinerja karyawan merupakan permasalahan yang akan selalu dihadapi manajemen disetiap perusahaan, oleh karna itu manajemen perlu mengetahui faktor-faktor yang mempengaruhi kinerja karyawan tersebut. Setelah itu perusahaan dapat mengambil kebijakan yang diperlukan, sehingga dapat meningkatkan kinerja karyawan sesuai dengan tujuan dan harapan perusahaan. Dalam pencapaian tujuan dibutuhkan kontribusi kinerja karyawan. Untuk meningkatkan kinerja karyawan adalah melalui perencanaan karir, pelatihan dan pengembangan karir pegawai. Perusahaaan memiliki tujuan meningkatkan keuntungan dan eksistensi agar dapat meningkatkan kinerja karyawan. Sedangkan bagi karyawan adalah untuk perbaikan dan peningkatan kualitas hidup serta diberi peluang untuk maju dan berkembang dalam kariernya.

Fenomena yang terjadi saat ini pada PT Bank Negara Indonesia (Persero) Tbk adalah adanya isu pengembangan bisnis menghadapi MEA dan menghadapi tantangan ekonomi digital dan menyelaraskan dengan program pemerintah ekonomi digital. Saat MEA berlangsung yang akan bersaing ketat adalah karyawan. Untuk itu, perlunya menyiapkan bekal kepada karyawan untuk menghadapi persaingan dan yang akan menjadi kunci dalam menghadapi MEA adalah labor skill. Mengapa? produk dan servis itu mudah ditiru, berbeda dengan SDM. Itulah mengapa perlunya memiliki perhatian besar pada kinerja SDM. Banyak faktor yang mempengaruhi kinerja dalam hal ini dapat dipastikan bahwa karyawan yang memiliki perencanaan karir, pelatihan dan pengembangan karir yang matang akan bertahan di dalam perusahaan, sedangkan karyawan yang memilih pindah ke perusahaan lain merupakan salah satu gejala lemahnya perhatian terhadap perencanaan karir, pelatihan dan pengembangan karir karyawan di dalam perusahaan.

Penelitian ini juga memfokuskan diri untuk menganalisis tingkat kinerja karyawan pada perusahaan setelah munculnya isu yang menyatakan bahwa karyawan teller bisa sampai usia 40 tahun artinya apabila mentok di teller yang berujung pada diangkat atau diakhiri dengan phk. Analisis kinerja ini di tinjau melalui variabel Perencanaan Karir, Pelatihan dan Pengembangan Karir. Tujuannya adalah dengan adanya Perencanaan Karir, Pelatihan dan Pengembangan Karir diharapkan Kinerja karyawan akan lebih meningkat lagi.

\section{Kajian Pustaka}

\section{Pengertian Kinerja Karyawan}

Kinerja berasal dari kata job performance atau actual performance yang berarti prestasi kerja atau prestasi sesungguhnya yang dicapai oleh seseorang. Mathis \& Jackson (2006:109) Kinerja merupakan rangkaian yang kritis antara strategi dan hasil organisasi. Bangun (2012:231) Kinerja (performance) adalah hasil pekerjaan yang dicapai seseorang berdasarkan persyaratan-persyaratan pekerjaan (job requirement).

\section{Pengertian Karir}

Maltis \& Jackson (2006:342) Karir adalah rangkaian posisi yang berkaitan dengan kerja yang ditempati seseorang sepanjang hidupnya. Dessler (2009:4) mendefinisikan karir adalah pekerjaan yang dimiliki seseorang selama bertahun-tahun.

\section{Pengertian Perencanaan karir}

Banyak hal yang menjadi penyebab sukses ataupun gagalnya seseorang dalam karirnya. Salah satunya adalah terkait dengan perencanaan karir. Perencanaan itu mesti ada sebelum kita melakukan kegiatan apapun, tentu saja agar kegiatan tersebut berjalan dengan lancer. Dessler (2009:5) Perencanaan Karir adalah proses penuh pertimbangan saat seseorang jadi memiliki pemahaman 
mengenai ketrampilan, pengetahuan, motivasi, dan karakteristik pribadi lainnya dan memantapkan rencana tindak untuk mencapai tujuan spesifik.

\section{Pengertian Pelatihan}

Menurut Mondy, (2008:210), pelatihan merupakan aktivitas-aktivitas yang dirancang untuk memberi para pembelajar pengetahuan dan keterampilan yang dibutuhkan untuk pekerjaan mereka saat ini. Dessler (2009:280) pelatihan adalah proses mengajar keterampilan yang dibutuhkan karyawan baru untuk melakukan pekerjaannya. Oleh Sikula dalam Mangkunegara (2015:44) pelatihan (training) adalah suatu proses pendidikan jangka pendek yang mempergunakan prosedur sistematis dan terorganisasi dimana pegawai manajerial mempelajari pengetahuan konseptual dan teoritis guna mencapai tujuan yang umum.

\section{Pengertian Pengembangan Karir}

Dessler (2009:5) Pengembangan karir adalah serangkaian aktivitas sepanjang hidup (seperti workshop) yang berkontribusi pada eksplorasi, pamantapan, keberhasilan, dan pencapaian karir seseorang. Mondy (2008:243) Pengembangan karir adalah pendekatan formal yang digunakan organisasi untuk memastikan bahwa orang dengan kualifikasi dan pengalaman yang tepat tersedia jika dibutuhkan. Handoko (2008:130) Pengembangan karir merupakan upaya-upaya pribadi seorang karyawan untuk mencapai suatu rencana karir.

\section{METODE}

\section{Definisi Operasional}

\section{Variabel Dependen (Dependent Variable)}

Kinerja Karyawan (Y) adalah hasil pekerjaan yang dicapai karyawan berdasarkan kualitas, kuantitas, pengetahuan dan kemampuan. Indikator kinerja karyawan sebagai berikut:

Kualitas

Kecepatan pelayanan seorang karyawan frontliner bank.

Kuantitas

Jumlah atau target yang dicapai seorang karyawan frontliner bank. Dinyatakan dalam istilah unit jumlah siklis aktivitas yang diselesaikan.

Pengetahuan dan Kemampuan

Kemampuan dan pengetahuan seorang karyawan frontliner bank dalam menyelesaikan pekerjaan dengan benar dan akurat tanpa kesalahan.

\section{Variabel Independen (Independent Variable)}

Perencanaan Karir $\left(\mathrm{X}_{1}\right)$ merupakan proses penuh pertimbangan seorang karyawan bagian frontliner bank mengenai kemampuan diri, minat, motivasi, dan informasi peluang untuk mencapai tujuan. Indikator-indikator perencanaan karir :

Karyawan frontliner bank sadar akan kemampuan diri. Karyawan frontliner bank mengetahui potensi dirinya.

Minat atau kepentingan karyawan frontliner bank. Karyawan frontliner bank memiliki niat untuk kemajuan karirnya.

Motivasi karyawan frontliner bank. Karyawan frontliner bank selalu termotivasi untuk kesuksesan karirnya.

Informasi peluang dan pilihan yang diberikan kepada karyawan frontliner bank. Perusahaan membimbing frontliner bank dalam mencapai karir yang disediakan.

Pelatihan $\left(\mathrm{X}_{2}\right)$ merupakan suatu usaha terencana untuk meningkatkan ketrampilan dan kemampuan pelaksanaan pekerjaan serta pengetahuan karyawan bagian frontliner bank melalui rancangan program pelatihan yang mencakup tujuan pelatihan, materi pelatihan, metode pelatihan, kualifikasi peserta dan banyaknya sesi latihan diharapkan dapat memperbaiki efektifitas kerja karyawan frontliner bank dalam mencapai target kinerja.

Adapun indikator dalam pelatihan adalah:

Tujuan Pelatihan. Peningkatan pemahaman terhadap etika kerja dan peningkatan ketrampilan karyawan frontliner bank dalam mencapai kinerja secara maksimal.

Materi Pelatihan karyawan frontliner bank. Materi pelatihan yang diperlukan untuk menunjang kemampuan untuk karyawan frontliner. 
Metode Pelatihan yang akan digunakan karyawan frontliner bank. Menggunakan metode parsipatif atau metode diskusi kelompok, konfrensi, simulasi, tes.

Kualifikasi Peserta. Karyawan tetap dan karyawan frontliner bank yang mendapat rekomedasi dari pimpinan.

Banyaknya sesi pelatihan yang dilakukan karyawan frontliner bank. Makin sering karyawan mendapat pelatihan maka kemampuan dan kemampuan karyawan akan cenderung meningkat.

Pengembangan Karir $\left(\mathrm{X}_{3}\right)$ merupakan proses mengindentifikasi potensi karir karyawan bagian frontliner bank melalui karyawan frontliner bank lebih dikenal atasan, kesetiaan karyawan frontliner bank terhadap perusahaan, mentor dan sponsor karyawan frontliner bank oleh atasan dan kesempatan bagi karyawan frontliner bank untuk tumbuh. Indikator-indikator pengembangan karir:

Karyawan frontliner bank lebih dikenal oleh manajer atau atasan sehingga mendapat peluang mencapai tujuan.

Kesetiaan karyawan frontliner bank kepada perusahaan.

Karyawan frontliner bank dibantu dan diberi nasehat atau saran karir oleh atasan mereka.

Kesempatan-kesempatan untuk tumbuh seperti program latihan, kursus dan melanjutkan pendidikan untuk karyawan frontliner bank.

\section{Teknik Analisis Data}

\section{Uji Reabilitas}

Reabilitas adalah alat untuk mengukur suatu koesioner yang merupakan alat pengukuran konstruk atau variabel. Suatu koesioner dapat dikatakan reabel/handal jika jawaban seseorang terhadap pertanyaan adalah konsisten atau stabil dari waktu ke waktu (Ghozali, 2005). Uji reabilitas adalah tingkat kestabilan suatu alat pengukur dalam mengukur suatu kejadian atau gejala. Semakin tinggi reabilitas suatu alat pengukur, semakin stabil pula alat pengukur alat tersebut. Dalam penghitungan Alpha, dingunakan alat bantu program computer yaitu SPSS for windows 16 dengan menggunakan model Alpha.

\section{Uji Validitas}

Ghozali (2001) menyatakan bahwa uji validitas digunakan untuk mengukur sah atau valid tidaknya suatu koesioner. Suatu koesioner dikatakan valid jika pertanyaan pada koesioner mampu untuk mengungkapkan sesuatu yang akan diukur oleh koesioner.

\section{Analisis Regresi Linier Berganda}

Dalam upaya menjawab permasalahan dalam penelitian ini maka digunakan analisis regresi linier berganda (Multiple Regression), Analisis regresi pada dasarnya adalah studi mengenai ketergantungan variabel dependen (terikat) dengan satu atau lebih variabel independen (variabel penjelasan/bebas), dengan tujuan untuk mengestimasi dan atau memprediksi rata-rata populasi atau nilai-nilai variabel dependen berdasarkan nilai variabel independen yang diketahui (Ghozali, 2005). Persamaan regresi dalam penelitian ini adalah untuk mengetahui seberapa besar pengaruh variabel independen atau bebas yaitu Perencanaan Karir $\left(X_{1}\right)$, Pelatihan $\left(X_{2}\right)$, Pengembangan Karir $\left(X_{3}\right)$ tehadap Kinerja Karyawan (Y).

Rumus matematis dari regresi berganda yang digunakan dalam penelitian ini adalah:

$$
\mathrm{Y}=\mathrm{a}+\mathrm{b}_{1} \mathrm{X}_{1}+\mathrm{b}_{2} \mathrm{X}_{2}+\mathrm{b}_{3} \mathrm{X}_{3}+\mathrm{e}
$$

Keterangan:

y : Kinerja Karyawan

a : Konstanta

$b_{1} \quad$ : Koefisien Regresi antara Perencanaan Karir dengan Kinerja Karyawan

$\mathrm{b}_{2} \quad$ : Koefisien Regresi antara Pelatihan dengan Kinerja Karyawan

$b_{3} \quad$ : Koefisien Regresi antara Pengembangan Karir dengan Kinerja Karyawan

$\mathrm{x}_{1} \quad$ : Perencanaan Karir

$\mathrm{X}_{2} \quad$ : Pelatihan

$\mathrm{X}_{3} \quad$ : Pengembangan Karir

E : error disturbances 


\section{Perhitungan Koefisien Korelasi (R)}

Koefisien korelasi digunakan untuk mengetahui kuatnya pengaruh variabel independen terhadap variabel dependen. Semakin besar nilai $R$, maka semakin kuat pengaruh variabel independen secara bersama-sama terhadap variabel dependen.

\section{Perhitungan Koefisien Determinasi $\left(\mathbf{R}^{2}\right)$}

Koefisien determinasi $\left(\mathrm{R}^{2}\right)$ pada intinya mengukur seberapa jauh kemampuan model dalam menerangkan variasi variabel independen. Nilai koefisien determinasi adalah antara nol dan satu. Nilai $\left(\mathrm{R}^{2}\right)$ yang kecil berarti kemampuan variabel-variabel independen dalam menjelaskan variasi variabel dependen sangat terbatas. Nilai yang mendekati satu berarti variabel-variabel independen memberikan hampir semua informasi yang dibutuhkan untuk memprediksi variasi variabel dependen (Ghozali, 2005).

\section{Uji F}

Menurut Ghozali (2011), uji statistic F pada dasarnya menunjukkan apakah semua variabel bebas yang dimasukkan dalam model mempunyai pengaruh secara simultan terhadap variabel dependen. Hipotesis nol $\left(\mathrm{H}_{0}\right)$ menyatakan bahwa semua variabel independen yang dimasukkan dalam model tidak mempunyai pengaruh secara simultan terhadap variabel dependen. Sedangkan $\mathrm{H}_{1}$ menyatakan bahwa semua variabel independen mempunyai pengaruh secara signifikan terhadap variabel dependen.

$\mathrm{H}_{0}$ diterima apabila $\mathrm{F}_{\text {hitung }}<\mathrm{F}_{\text {tabel }}$

$\mathrm{H}_{0}$ ditolak apabila $\mathrm{F}_{\text {hitung }}>\mathrm{F}_{\text {tabel }}$

Ketentuan penerimaan atau menolak hipotesis adalah sebagai berikut:

Jika nilai signifikansi $\leq 0,05$ maka regresi dapat digunakan untuk uji hipotesis.

Jika nilai signifikansi $\geq 0,05$ maka regresi tidak dapat digunakan untuk uji hipotesis.

\section{Uji t (Parsial)}

Uji t pada dasarnya menunjukkan seberapa jauh pengaruh variabel indipenden secara individual dalam menerangkan variabel independen (Ghozali, 2005).

\section{HASIL DAN PEMBAHASAN}

Sebelum menganalisis hasil penelitian mengenai Pengaruh Perencanaan Karir, Pelatihan dan Pengembangan Karir terhadap Kinerja Karyawan PT. Bank Negara Indonesia (Persero) Tbk Samarinda, sebelumnya dilakukan Uji Validitas dan Reabilitas yaitu sebagai berikut:

Uji Validitas

\section{Perencanaan Karir $\left(\mathbf{X}_{1}\right)$}

Hasil Uji Validitas pada 4 item pernyataan (P1, P2, P3, dan P4) Variabel Perencanaan Karir untuk $\mathrm{r}$ hasil (Corrected Item - Total Correlation) berada diatas dari nilai $\mathrm{r}$ tabel : 0,3 sehingga seluruh item pertanyaan yaitu valid.

\section{Pelatihan $\left(\mathbf{X}_{2}\right)$}

Hasil Uji Validitas pada 4 item pernyataan (P1, P2, P3, dan P4) Variabel Pelatihan untuk r hasil (Corrected Item - Total Correlation) berada diatas dari nilai $\mathrm{r}$ tabel : 0,3 sehingga seluruh item pertanyaan yaitu valid.

\section{Pengembangan Karir $\left(\mathbf{X}_{3}\right)$}

Hasil Uji Validitas pada 4 item pernyataan (P1, P2, P3, dan P4) Variabel Pelatihan untuk r hasil (Corrected Item - Total Correlation) berada diatas dari nilai $\mathrm{r}$ tabel : 0,3 sehingga seluruh item pertanyaan yaitu valid.

\section{Kinerja Karyawan (Y)}

Hasil Uji Validitas pada 4 item pernyataan (P1, P2, P3, dan P4) Variabel Kinerja Karyawan untuk $\mathrm{r}$ hasil (Corrected Item - Total Correlation) berada diatas dari nilai $\mathrm{r}$ tabel : 0,3 sehingga seluruh item pertanyaan yaitu valid. 


\section{Uji Reabilitas}

\section{Perencanaan Karir $\left(\mathbf{X}_{1}\right)$}

Nilai $\mathrm{r}$ Alpha : 0,808 > nilai $\mathrm{r}$ table; 0,3, maka 4 item pertanyaan variabel Perencanaan Karir adalah reliabel (nilai $r$ alpha berdasarkan lampiran 5).

\section{Pelatihan $\left(\mathbf{X}_{2}\right)$}

Nilai $\mathrm{r}$ Alpha : 0,816 > nilai $\mathrm{r}$ table ; 0,3 maka 4 item pertanyaan varibel Pelatihan adalah reliabel (nilai $\mathrm{r}$ alpha berdasarkan lampiran 5).

\section{Pengembangan Karir $\left(\mathbf{X}_{3}\right)$}

Nilai $r$ Alpha : 0,811 > nilai $r$ table ; 0,3 maka 4 item pertanyaan varibel Pengembangan Karir adalah reliabel (nilai $r$ alpha berdasarkan lampiran 5).

\section{Kinerja Karyawan (Y)}

Nilai $r$ Alpha : 0,834 > nilai $r$ table ; 0,3 maka 3 item pertanyaan variabel Kinerja Karyawan. adalah reliabel (nilai $r$ alpha berdasarkan lampiran 5).

\section{Analisis Pengaruh Perencanaan Karir, Pelatihan dan Pengembangan Karir terhadap Kinerja} Karyawan PT. Bank Negara Indonesia (Persero) Tbk Samarinda.

Pengaruh Perencanaan Karir, Pelatihan dan Pengembangan Karir terhadap Kinerja Karyawan PT. Bank Negara Indonesia (Persero) Tbk Samarinda dapat dilihat dari koefisien Korelasi (R) dan Koefisien Determinasi (R Square), yang dapat dilihat pada Tabel 4.23. Berikut ini:

Uji-F dilakukan untuk mengetahui kelayakan model regresi pada Pengaruh Perencanaan, Pelatihan dan Pengembangan Karir PT. Bank Negara Indonesia (Persero) Tbk Samarinda.

Cara mengetahuinya adalah dengan membandingkan nilai Fhitung dan Ftabel pada tingkat kepercayaan (tingkat signifikan) $95 \%$ atau $\alpha=0,05$, dengan derajat kebebasan (df) untuk pembilang 3 (k) dan untuk penyebut $46(\mathrm{n}-\mathrm{k}-1=50-3-1)$. Untuk lebih jelasnya dapat dilihat pada Tabel 4.24. berikut ini:

\section{Variabel Perencanaan Karir, Pelatihan dan Pengembangan Karir PT. Bank Negara Indonesia (Persero) Tbk Samarinda}

Uji-t dilakukan untuk mengerahui apakah variabel Perencanaan Karir, Pelatihan dan Pengembangan Karir secara parsial (satu-satu) berpengaruh signifikan terhadap Kinerja Karyawan PT. Bank Negara Indonesia (Persero) Tbk Samarinda.

Berdasarkan hasil analisis, diketahui persamaan dari regresi antara Perencanaan Karir $\left(\mathrm{X}_{1}\right)$, Pelatihan $\left(\mathrm{X}_{2}\right)$, dan Pengembangan Karir $\left(\mathrm{X}_{3}\right)$ terhadap Kinerja Karyawan PT. Bank Negara Indonesia Samarinda (Y), yaitu sebagai berikut:

$$
\mathrm{Y}=-0.326+0,624 \mathrm{X}_{1}+0,355 \mathrm{X}_{2}+0,109 \mathrm{X}_{3}
$$

Karena:

$\mathrm{Y}=$ Kinerja Karyawan

a $=$ Konstanta

$\mathrm{X}_{1}=$ Perencanaan Karir

$\mathrm{X}_{2}=$ Pelatihan

$\mathrm{X}_{3}=$ Pengembangan Karir

$\mathrm{b}$ = Koefisien regresi yaitu besarnya perubahan yang terjadi pada $\mathrm{Y}$ jika satu unit perubahan pada variabel bebas (variabel $\mathrm{x}$ ).

Persamaan garis regresi tersebut mengandung arti bahwa:

Koefisien regresi $X_{1}$ sebesar 0,624; $X_{2}$ sebesar 0,355; $X_{3}$ sebesar 0,109. Hal ini berarti bahwa setiap penambahan (karena tanda + ) Perencanaan Karir $\left(X_{1}\right)$, Pelatihan $\left(X_{2}\right)$ dan Pengembangan Karir $\left(\mathrm{X}_{3}\right)$ akan menaikan Kinerja Karyawan PT. Bank Negara Indonesia Samarinda (Y) masing-masing sebesar $62,4 \%, 35,5 \%$ dan 10,9 \% atau dengan kata lain Perencanaan Karir $\left(\mathrm{X}_{1}\right)$, Pelatihan $\left(\mathrm{X}_{2}\right)$ dan Pengembangan Karir $\left(\mathrm{X}_{3}\right)$ memberikan pengaruh positif terhadap Kinerja Karyawan PT. Bank Negara Indonesia (Persero) Tbk Samarinda (Y). 
Nilai elastisitas Perencanaan Karir $\left(\mathrm{X}_{1}\right)$, Pelatihan $\left(\mathrm{X}_{2}\right)$, dan Pengembangan Karir $\left(\mathrm{X}_{3}\right)$ adalah masing-masing 0,624, 0,355 dan 0,109 dengan demikian diketahui bahwa nilai elastisitas Perencanaan Karir $\left(\mathrm{X}_{1}\right)$, Pelatihan $\left(\mathrm{X}_{2}\right)$, dan Pengembangan Karir $\left(\mathrm{X}_{3}\right)$ terhadap Kinerja Karyawan PT. Bank Negara Indonesia (Persero) Tbk Samarinda $(\mathrm{Y})<1$ berarti ini elastis, yang bermakna bahwa elastisitas Perencanaan Karir $\left(\mathrm{X}_{1}\right)$, Pelatihan $\left(\mathrm{X}_{2}\right)$, dan Pengembangan Karir $\left(\mathrm{X}_{3}\right)$ yang diminta lebih kecil dari pada penambahan Kinerja Karyawan PT. Bank Negara Indonesia (Persero) Tbk Samarinda (Y). Untuk Lebih jelasnya perbandingan $t_{\text {hitung }}$ dengan $t_{\text {tabel }}$ dari masing-masing variabel tersebut dapat diuraikan sebagai berikut:

\section{Variabel Perencanaan Karir (X1)}

Nilai thitung 0,05 (47) Perencanaan Karir (X1) adalah 8.677 sedangkan nilai ttabel 0,05 (47) adalah 1,97 sehingga dapat dilihat bahwa thitung > ttabel dan hal ini juga dibuktikan dengan nilai signifikan 0,000 $<0,05$ yang berarti Perencanaan Karir berpengaruh positif dan signifikan terhadap Kinerja Karyawan PT. Bank Negara Indonesia (Persero) Tbk Samarinda.

\section{Variabel Pelatihan (X2)}

Nilai thitung 0,05 (47) Pelatihan (X2) adalah, sedangkan nilai ttabel 0,05 (47) adalah 4.845, sedangkan ttabel 0,05 (47) adalah 1,97 sehingga dapat dilihat bahwa thitung > ttabel dan hal ini juga dibuktikan dengan nilai signifikan $0,000<0,05$ yang berarti Pelatihan berpengaruh positif dan signifikan terhadap Kinerja Karyawan PT> Bank Negara Indonesia (Persero) Tbk Samarinda.

\section{Variabel Pengembangan Karir (X3)}

Nilai thitung 0,05 (47) Pengembangan Karir (X1) adalah 2.048 sedangkan nilai ttabel 0,05 (47) adalah 1,97 sehingga dapat dilihat bahwa thitung > ttabel dan hal ini juga dibuktikan dengan nilai signifikan 0,046 $<0,05$ yang berarti Pengembangan Karir berpengaruh positif dan signifikan terhadap Kinerja Karyawan PT. Bank Negara Indonesia (Persero) Tbk Samarinda.

\section{Pembahasan}

Setelah menilai model secara keseluruhan dan menguji hubungan kausalitas seperti yang dihipotesiskan, tahap selanjutnya adalah pembahasan hasil penelitian sebagai berikut:

\section{Pengaruh Perencanaan Karir terhadap Kinerja Karyawan}

Hasil penelitian menunjukkan bahwa perencanaan karir berpengaruh positif dan signifikan terhadap kinerja karyawan PT. Bank Negara Indonesia (Persero) Tbk Samarinda. Ditunjukkan dengan kesadaran karyawan PT. Bank Negara Indonesia (Persero) Tbk Samarinda mengenai kemampuan potensi diri mereka sudah sangat baik, kepentingan dan niat karyawan untuk kemajuan karir mereka sudah sangat baik, motivasi karyawan mencapai kesuksesan karir mereka sudah sangat baik, serta informasi dan pilihan karir karyawan sudah baik. Perencanaan karir karyawan sudah baik dibuktikan dipenelitian ini. Hal ini mengindikasikan bahwa perencanaan karir mengakibatkan meningkatnya kinerja karyawan PT. Bank Negara Indonesia (Persero) Tbk Samarinda. Atau dengan kata lain semakin tinggi perencanaan karir maka kinerja karyawan juga semakin tinggi.

Hasil penelitian ini sesuai dengan penelitian yang dilakukan oleh Rimper (2014) menunjukkan bahwa perencanaan karir berpengaruh positif dan signifikan terhadap kinerja karyawan.

\section{Pengaruh Perlatihan terhadap Kinerja Karyawan}

Hasil penelitian menunjukkan bahwa pelatihan memiliki pengaruh positif dan signifikan terhadap kinerja karyawan. Ditunjukkan dengan pemahaman karyawan mengenai etika kerja dan ketrampilan kerja sudah sangat baik, materi pelatihan yang diberikan perusahaan sudah sangat baik, metode pelatihan yang diberikan perusahaan sudah baik, serta banyaknya sesi pelatihan yang dikuti karyawan sudah baik. Pelatihan pada PT. Bank Negara Indonesia (Persero) Tbk Samarinda sudah baik dengan dibuktikan dipenelitian ini. Hal ini mengindikasikan bahwa pelatihan mengakibatkan meningkatnya kinerja karyawan PT. Bank Negara Indonesia (Persero) Tbk Samarinda. Atau dengan kata lain semakin tinggi pelatihan yang diikuti karyawan maka kinerja karyawan pada PT. Bank Negara Indonesia (Persero) Tbk Samarinda juga semakin tinggi.

Hasil penelitian ini sesuai dengan penelitian yang dilakukan Sahanggamu menunjukkan bahwa Pelatihan berpengaruh positif dan signifikan terhadap Kinerja Karyawan.

\section{Pengaruh Pengembangan Karir Terhadap Kinerja Karyawan}


Hasil penelitian menunjukkan bahwa pengembangan karir memiliki pengaruh positif dan signifikan terhadap kinerja karyawan. Ditunjukkan dengan karyawan lebih dikenal atasan atau manajer mereka sudah baik, kesetiaan karyawan kepada perusahaan sudah sangat baik, atasan atau manajer membantu karyawan dan memberikan nasehat karir kepada karyawan sudah sangat baik dan kesempatan karyawan untuk mengikuti program latihan, kursus atau melanjutkan pendidikan sudah baik. Pengembangan karir PT. Bank Negara Indonesia (Persero) Tbk Samarinda sudah baik dengan dibuktikan dipenelitian ini. Hal ini mengindikasikan bahwa pengembangan karir mengakibatkan meningkatnya kinerja karyawan PT. Bank Negara Indonesia (Persero) Tbk Samarinda. Atau dengan kata lain semakin tinggi pengembangan karir yang diberikan kepada karyawan maka kinerja karyawan pada PT. Bank Negara Indonesia (Persero) Tbk Samarinda juga semakin tinggi.

Hasil penelitian ini sesuai dengan penelitian yang dilakukan oleh Rahma (2015) yang menunjukkan bahwa Pengembangan Karir berpengaruh positif dan signifikan terhadap Kinerja Karyawan.

\section{SIMPULAN}

Berdasarkan hasil pernelitian dan pembahasan yang telah dikemukakan sebelumnya mengenai Perencanan Karir, Pelatihan dan Pengembangan Karir terhadap Kinerja Karyawan PT. Bank Negara Indonesia (Persero) Tbk Samarinda diperoleh kesimpulan sebagai berikut:

Perencanaan Karir berpengaruh positif dan signifikan terhadap Kinerja Karyawan. Perencanaan karir karyawan pada PT. Bank Negara Indonesia (Persero) Tbk Samarinda sudah baik. Hal ini menunjukkan bahwa perencanaan karir mengakibatkan meningkatnya kinerja karyawan PT. Bank Negara Indonesia (Persero) Tbk Samarinda. Atau dengan kata lain semakin tinggi perencanaan karir maka kinerja karyawan juga semakin tinggi.

Pelatihan berpengaruh positif dan signifikan terhadap Kinerja Karyawan. Pelatihan karyawan sudah baik sehingga berpengaruh terhadap kinerja yang dihasilkan juga baik. Hal ini menunjukkan bahwa pemberian pelatihan yang akan berpengaruh terhadap meningkatnya kinerja karyawan PT. Bank Negara Indonesia (Persero) Tbk Samarinda. Semakin tinggi pelatihan yang dilakukan karyawan maka kinerja karyawan pada PT. Bank Negara (Persero) Tbk Samarinda juga akan semakin tinggi.

Pengembangan Karir berpengaruh positif dan signifikan terhadap Kinerja Karyawan. Pengembangan karir karyawan sudah baik sehingga berpengaruh terhadap kinerja yang dihasilkan juga baik. Hal ini menunjukkan bahwa bahwa pengembangan karir berpengaruh terhadap meningkatnya kinerja karyawan PT. Bank Negara Indonesia (Persero) Tbk Samarinda.

\section{DAFTAR PUSTAKA}

Bangun, Wilson. 2012. Manajemen Sumber Daya Manusia: Penilaian Kinerja Karyawan. Cetakan Pertama. Erlangga. Bandung.

Dessler, Gary. 2009. Manajemen Sumber Daya Manusia. Terj. Edisi kesepuluh jilid 2. PT Macanan Jaya Cemerlang. Jakarta.

Ghozali, Imam. 2005. Aplikasi Analisis Multirative dengan Program SPSS. Edisi ketiga. Universitas Diponegoro. Semarang.

Handoko, T. Hani. 2008. Manajemen Personalia dan Sumber Daya Manusia. BPFE. Yogyakarta

Mangkunegara, Anwar Prabu. 2015. Manajemen Sumber Daya Manusia Perusahaan. Cetakan Keduabelas. PT. Remaja Rosdakarya. Bandung.

Mathis, Robert L. and John H. Jackson. 2006. Manajemen Sumber Daya Manusia. Salemba Empat. Jakarta..

Mondy, R. Wayne. 2008. Manajemen Sumber Daya Manusia. Cetakan kedua. Erlangga. Jakarta.

Priyanto, Duwi. 2008. Mandiri Belajar SPSS. MediaKom. Yogyakarta.

Rahma, Siti. Pratiwi, Dini dan Ismail, Zakaria. 2015. Analisis Pengaruh Pelatihan dan Pengembangan karir terhadap Produktivitas Kerja Pegawai Pada PT. Bank Sumsel Babel Cabang Pangkalpinang. Skripsi: STIE-IBEK Bangka Belitung. 
Rimper, Rinna R., dan Kawet, Lotje. 2014. Pengaruh Perencanaan Karir Dan Self Efficacy Terhadap Kinerja Karyawan Pada PT. PLN (Persero) Area Manado. Skripsi: Universitas Sam Ratulangi Manado.

Sahanggamu, Patricia M., dan Mandey, Silvya L. 2014. Pengaruh Pelatihan Kerja, Motivasi, Dan Disiplin Kerja Terhadap Kinerja Karyawan Pada PT. Bank Perkreditan Rakyat Dana Raya. Skripsi: Universitas Sam Ratulangi Manado.

Sugiyono. 2012. Metode Penelitian Bisnis. Cetakan Kesembilan. CV. Alfabeta. Bandung. Wahyono, Teguh. 2008. Cara Mudah Melakukan Statistik Dengan SPSS. GAVA MEDIA. Yogyakarta. 